\title{
Pertumbuhan Kembali Asystasia gangetica Pasca Aplikasi Growth Hormone pada Stek di Naungan yang Berbeda
}

\author{
N R Kumalasari', F M Abdillah', L Khotijah', L Abdullah'
}

\section{Corresponding email:}

nurrkumala@gmail.com

'Department of Animal Nutrition and Feed Technology, Faculty of Animal Science, IPB University (Bogor Agricultural University)

\section{ABSTRACT}

Asystasia gangetica is one of the plantation weeds that grows under shading area and has potential use as forage. The aim of this experiment was to analyze the cutting stem of $A$. gangetica regrowth that immersed on growth promotor hormone under different plant shadding. The treatments were arranged A. gangetica plant in a Completely Randomized Block design that consisted of 2 hormone (auxin and cytokinin) and 5 shading (green house, open space, under Indigofera zollingeriana tree, under Bauhinia sp and Glyricidia sepium). The results showed that residual hormones have small effect on the number of $A$. gangetica primary branches only. Shading environment increased A. gangetica regrowth, especially on plant height, number of branches and flower development, except Bauhinia shading. It concluded that $A$. gangetica has potential to develop as ruminant forage due to high regrowth capability.

Keywords: Asystasia gangetica, hormone residu, plant regrowth, plant shading

\section{ABSTRAK}

Aystasia gangetica merupakan salah satu gulma perkebunan yang dapat tumbuh dangan baik pada kondisi ternaungi dan memiliki potensi sebagai hijauan pakan. Tujuan penelitian ini adalah menganalisis pertumbuhan kembali stek A. gangetica yang telah direndam dalam hormon pertumbuhan dibawah naungan tumbuhan yang berbeda. Penelitian ini dirancang menggunakan Rancangan Acak Kelompok yang terdiri dari hormon auksin dan sitokinin dengan 5 naungan (rumah kaca, ruangan terbuka, naungan pohon Indigofera zollingeriana, Bauhinia sp dan Glyricidia sepium). Hasil penelitian menunjukkan bahwa residu hormon memiliki pengaruh pada jumlah cabang primer. Naungan meningkatkan pertumbuhan kembali A. gangetica, khususnya tinggi tanaman, jumlah cabang dan perkembangan bunga, kecuali naungan Bauhinia sp. Penelitian ini menyimpulkan bahwa A. gangetica memiliki potensi untuk dikembangkan sebagai hijauan pakan ruminansia karena kemampuan pertumbuhan kembali yang tinggi.

Kata kunci: Asystasia gangetica, naungan, pertumbuhan kembali, residu hormon 


\section{PENDAHULUAN}

Asystasia gangetica L merupakan salah satu jenis gulma yang banyak tumbuh di lahan pertanian (Kumalasari dan Sunardi 2014) dan perkebunan (Khalil 2016), terutama perkebunan kelapa sawit (Ramdani et al. 2016). A. gangetica di Indonesia dapat ditemukan di Sumatera, Jawa Barat, Jawa Tengah, dan Kalimantan (Tjitrosoedirdjo 2015). A. gangetica memiliki palatabilitas dan daya cerna yang tinggi, sehingga dapat digunakan sebagai pakan hewan (Grubben 2004). A. gangetica memiliki kadar protein kasar sebesar 19,3\% (Adigun et al. 2014) hingga $33 \%$ tergantung pada bagian tumbuhan yang dimanfaatkan (Putra 2018).

Pemanfaatan $A$. gangetica saat ini banyak dilakukan dengan pengambilan atau pemanenan A. gangetica yang tumbuh secara alami di berbagai wilayah (Khalil 2016). Perkembangbiakan A. gangetica dapat terjadi secara alami maupun budidaya dengan biji (Kumalasari et al. 2018a) atau batang (Kumalasari et al. 2018b). Tumbuhan memiliki potensi yang baik sebagai tanaman pakan dengan persyaratan memiliki kandungan nutrien yang baik, produksi biomas yang tinggi dan kemampuan tumbuh kembali dengan cepat.

Pemanfaatan A. gangetica secara komersial dalam jangka panjang sebagai pakan ternak memerlukan budidaya yang tepat agar tersedia secara kontinyu dan terjaga kualitasnya. Perkembangbiakan A. gangetica dengan menggunakan stek yang direndam dengan hormon auksin dan sitokinin menghasilkan produksi dan kualitas hijauan yang baik (Kumalasari et al. 2018). Informasi pertumbuhan kembali A. gangetica diperlukan untuk mendapatkan kontinuitas suplai hijauan pakan. Tujuan penelitian ini adalah menganalisis pengaruh berbagai naungan dan rendaman larutan hormon saat awal penanaman pada pertumbuhan kembali stek $A$. gangetica.

\section{METODE}

Bahan-bahan yang digunakan dalam penelitian ini yaitu tanaman A. gangetica pada polybag yang sudah dipanen pertama. Tanaman A. gangetica yang digunakan adalah tanaman yang sudah dipanen sekali dengan ketinggian 5 $\mathrm{cm}$. Setiap polybag yang berisi bibit $A$. gangetica tersebut dipindahkan ke area naungan yang ditentukan.

Persiapan Bibit stek A. gangetica dilakukan dengan merendam di dalam larutan auksin dan sitokinin selama 15 menit, ditanam pada polybag dan ditempatkan di rumah kaca sampai masa panen pertama. Persiapan areal tanam pada naungan yang ditetapkan berupa tutupan tajuk pohon Glyricidia sepium, Bauhinia sp dan Indigofera zollingeriana, tumbuhan liar di bawahnya dipangkas dan dibentuk bedengan dengan ukuran 2x2 meter. Bibit $A$. gangetica yang telah dipanen dengan tinggi $5 \mathrm{~cm}$ ditempatkan di setiap bedengan di bawah tajuk pohon dengan jarak antara tanaman $50 \mathrm{~cm}$. Dalam satu bedengan terdapat 11 polybag $A$. gangetica selanjutnya disiram dan diukur intensitas cahaya matahari di dalam rumah kaca, naungan Glyricidia sepium, naungan Bauhinia sp lahan terbuka, dan naungan Indigofera setiap pagi (10.00) dan sore (15.00). Peubah yang diamati adalah jumlah daun, tinggi tanaman, jumlah cabang calon bunga, dan jumlah bunga mekar.

Pemanenan A. gangetica dilakukan setelah berumur 50 hari, kemudian ditimbang bobot segarnya dan dikeringkan dengan sinar matahari selama 3 hari dan di oven dengan suhu $60^{\circ} \mathrm{C}$. Hasil sampel diblender, kemudian dianalisis proksimat (AOAC 2005), yaitu kadar air (KA), protein kasar (PK), serat kasar (SK), lemak kasar (LK) dan abu. Penelitian ini menggunakan Rancangan Acak Kelompok. Analisis data dilakukan dengan menggunakan Linier Model dengan software R 3.4.2, jika terdapat faktor yang berbeda nyata maka diuji lanjut dengan menggunakan Duncan Multiple Range Test.

\section{HASIL DAN PEMBAHASAN}

\section{Pertumbuhan Kembali Stek A. gangetica yang Direndam Growth Hormone}

Hasil penelitian ini menunjukkan bahwa perendaman stek pada hormon auksin dan sitokinin sudah tidak memberikan pengaruh pada parameter pertumbuhan kembali $A$. gangetica, kecuali pada jumlah cabang primer (Tabel 1). Pertumbuhan kembali A.gangetica yang steknya direndam hormon auksin cenderung memberikan pertambahan jumlah cabang primer $(4,70$ cabang) lebih tinggi dibandingkan sitokinin $(4,25$ cabang). Pengaruh residu hormon pada tinggi tanaman, jumlah daun, cabang sekunder, cabang tersier, calon bunga dan bunga mekar tidak terlihat pada pertumbuhan A.gangetica.

Lama pengaruh residual hormon selama pertumbuhan tanaman dapat dilihat pada Gambar 1. Pertumbuhan tanaman dalam hal ini tinggi tanaman memiliki perbedaan nyata $(\mathrm{p}<0,1)$ pada minggu pertama dan kedua pengamatan. Pada minggu ke tiga hingga minggu ke tujuh, perbedaan tinggi tanaman tidak nyata. Pengaruh residual hormon ini pada minggu awal penelitian ini diduga berpengaruh pada pembentukan

Tabel 1 Pengaruh residu hormon auksin dan sitokinin pada pertumbuhan A. gangetica

\begin{tabular}{lll}
\hline Parameter & Auksin & Sitokinin \\
\hline Tinggi tanaman (cm) & $36,62 \pm 8,55$ & $34,11 \pm 10,06$ \\
Jumlah daun (helai) & $110,45 \pm 35,50$ & $115,44 \pm 33,54$ \\
Jumlah cabang primer*(cabang) & $4,70 \pm 2,75^{\mathrm{a}}$ & $4,25 \pm 2,42^{\mathrm{b}}$ \\
Jumlah cabang sekunder (cabang) & $2,82 \pm 1,29$ & $3,26 \pm 1,33$ \\
Jumlah cabang tersier (cabang) & $1,20 \pm 0,85$ & $1,37 \pm 0,8$ \\
Jumlah calon bunga (kuncup) & $19,28 \pm 10,52$ & $19,56 \pm 10,31$ \\
Jumlah bunga mekar (kuntum) & $4,20 \pm 2,54$ & $4,39 \pm 2,53$ \\
\hline
\end{tabular}

Superskrip yang perbeda pada baris yang sama menunjukkan perbedaan cenderung
nyata pada $p<0,1$ 


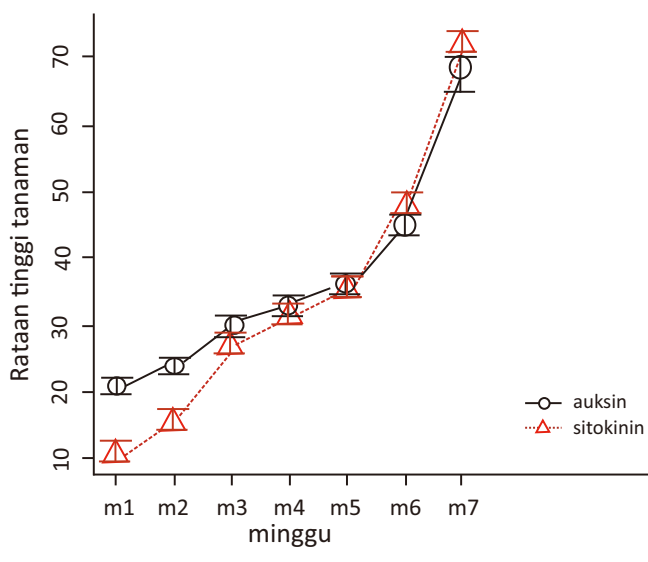

Grambar 1 Rataan tinggi tanaman A. gangetica selama pemeliharaan

cabang primer. Menurut Skalický et al (2018), hormon auksin memiliki kemampuan menstimulasi pertumbuhan cabang pada masa vegetatif.

Perendaman stek hormon auksin dan sitokinin sangat berpengaruh pada daya tumbuh stek dan pertumbuhan pertama tanaman A. gangetica (Kumalasari et al. 2018b). Menurut Rastogi et al. (2013), pengaruh aplikasi hormon pada pertumbuhan tanaman tergantung pada dosis yang diberikan dan waktu pengulangan aplikasi. Pada pertumbuhan kedua, pengaruh hormon pada penelitian ini sangat kecil karena tidak ada penambahan kembali hormon sebelum dan selama pemeliharaan.

\section{Intensitas Cahaya pada Berbagai Naungan}

Hasil pengukuran intensitas cahaya menunjukkan bahwa intensitas cahaya matahari pada pukul 10.00 lebih tinggi dibandingkan pukul 15.00 (Tabel 2). Intensitas cahaya tertinggi pada lahan terbuka sedangkan intensitas cahaya terendah pada naungan Bauhinia yang mencapai 4,8\% pada pukul 10.00 dan $5,5 \%$ pukul 15.00 dari kondisi lahan terbuka. Menurut Rijkers et al. (2000), tinggi tanaman dan variabel daun berpengaruh pada cahaya matahari yang mencapai permukaan tanah. Naungan Bauhinia yang memiliki daun lebar dapat menyebabkan cahaya matahari tertutup lebih banyak dibandingkan naungan Glyricidia sepium (gamal) dan Indigofera yang memiliki daun lebih sempit.

\section{Pertumbuhan Kembali A. gangetica pada Berbagai Naungan}

Hasil penelitian ini menunjukkan bahwa A. gangetica dapat hidup dengan sangat baik pada naungan tanaman

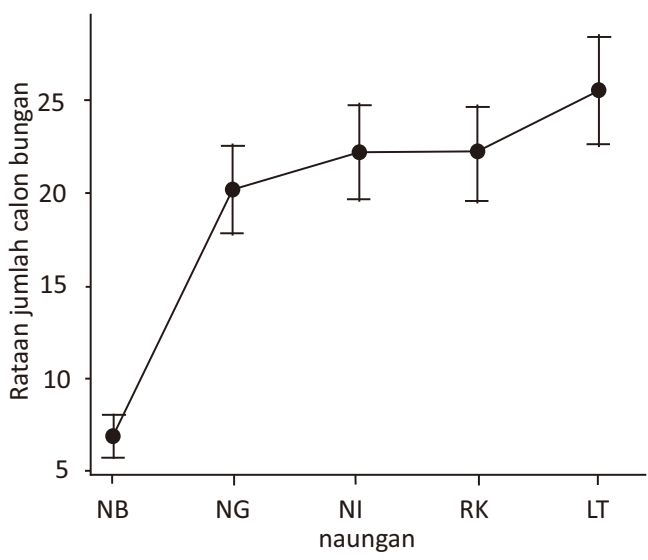

Gambar 2 Rataan jumlah calon bunga pada naungan yang berbeda

legum, terutama naungan gamal dan Indigofera (Tabel 3). Pada naungan gamal secara nyata $(\mathrm{p}<0,01)$ meningkatkan pertumbuhan pada peubah tinggi tanaman $(38,93 \mathrm{~cm})$ dan jumlah calon bunga (20,24 kuncup) dibandingkan rumah kaca, naungan legum lain maupun tempat terbuka. Pada peubah lainnya, A. gangetica cenderung naik $(\mathrm{p}<0,1)$ yaitu cabang sekunder (4,02 kuncup), cabang tersier (1,73 cabang) dan jumlah bunga mekar (5,07 bunga).

Pada tempat terbuka, jumlah daun nyata $(129,88$ helai) lebih banyak dan pertumbuhan jumlah calon bunga (25,57 kuncup) cenderung lebih tinggi dibandingkan kondisi ternaungi (Gambar 2). Hal ini karena intensitas cahaya menstimulasi perkembangan jumlah dan warna daun (Kumalasari et al. 2017a) serta pembentukan bunga (Kumalasari et al. 2017b). Jumlah calon bunga ini pada akhirnya berpengaruh pada jumlah bunga mekar dan polong yang dapat terbentuk oleh tanaman. Secara keseluruhan hasil penelitian menunjukkan bahwa $A$. gangetica dapat hidup dengan baik pada kondisi ternaungi hingga 29,3\% dari kondisi lahan terbuka. Menurut Shao et al. (2014), tanaman penutup tanah berdaun lebar memiliki tingkat aktivitas fotosintesis dan pergerakan stomata terbaik pada naungan sekitar 30\%.

\section{SIMPULAN}

Asystasia gangetica dapat tumbuh dengan baik pada kondisi ternaungi tanaman lain dengan kemampuan tumbuh kembali tanaman yang cukup baik, terutama pada tinggi tanaman, jumlah daun, jumlah cabang dan pembungaan. Aplikasi hormon auksin dan sitokinin yang digunakan untuk merendam stek A. gangetica pada awal penanaman sudah hampir tidak berpengaruh pada pertumbuhan kembali $A$. gangetica setelah panen pertama.

Tabel 2 Rataan dan persentase intensitas cahaya pada pukul 10.00 dan 15.00

\begin{tabular}{llllll}
\hline Parameter & LT & RK & NB & NG & NI \\
\hline Rataan intensitas cahaya pukul 10.00 (lux) & 27595,70 & 19695,60 & 1308,80 & 5183,10 & 6789,90 \\
Persentase intensitas cahaya naungan pukul 10.00 & 100,00 & 72,10 & 4,80 & 19,30 & 24,90 \\
Rataan intensitas cahaya pukul 15.00 (lux) & 14581,40 & 10833,90 & 782,50 & 4383,1 & 4877,4 \\
Persentase intensitas cahaya naungan pukul 15.00 & 100,00 & 76,10 & 5,50 & 29,30 & 33,50 \\
\hline
\end{tabular}

LT=lahan terbuka, RK=rumah kaca, NB=naungan Bauhinia, NG=naungan Glyricidia sepium , dan NI=naungan Indigofera 
Tabel 3 Pengaruh naungan pada pertumbuhan A. gangetica

\begin{tabular}{llllll}
\hline Parameter & LT & RK & NB & NG & $N I$ \\
\cline { 2 - 6 } Tinggi tanaman (cm) & $32,74 \pm 9,25^{\mathrm{b}}$ & $36,53 \pm 10,54^{\mathrm{ab}}$ & $32,47 \pm 7,03^{\mathrm{b}}$ & $38,93 \pm 9,48^{\mathrm{a}}$ & $36,14 \pm 9,43^{\mathrm{ab}}$ \\
Jumlah daun (helai) & $129,88 \pm 39,08^{\mathrm{a}}$ & $107,28 \pm 30,57^{\mathrm{b}}$ & $85,28 \pm 24,62^{\mathrm{c}}$ & $117,28 \pm 35,54^{\mathrm{ab}}$ & $125,00 \pm 37,43^{\mathrm{ab}}$ \\
Jumlah (cabang) & & & & & \\
$\quad$ & $3,50 \pm 1,05^{\mathrm{c}}$ & $5,52 \pm 1,25^{\mathrm{a}}$ & $4,07 \pm 1,41^{\mathrm{bc}}$ & $5,20 \pm 1,45^{\mathrm{ab}}$ & $4,08 \pm 1,01^{\mathrm{bc}}$ \\
$\quad$ cabang primer & $2,32 \pm 0,850^{\mathrm{b}}$ & $3,05 \pm 1,15^{\mathrm{b}}$ & $3,07 \pm 1,73^{\mathrm{b}}$ & $4,02 \pm 1,43^{\mathrm{a}}$ & $2,71 \pm 0,84^{\mathrm{b}}$ \\
$\quad$ cabang sekunder* & $1,17 \pm 0,71^{\mathrm{b}}$ & $1,68 \pm 1,04^{\mathrm{a}}$ & $0,74 \pm 0,52^{\mathrm{b}}$ & $1,73 \pm 1,05^{\mathrm{a}}$ & $1,08 \pm 0,65^{\mathrm{b}}$ \\
$\quad$ cabang tersier* & $25,57 \pm 12,35^{\mathrm{a}}$ & $22,22 \pm 10,51^{\mathrm{a}}$ & $6,91 \pm 4,41^{\mathrm{b}}$ & $20,24 \pm 10,20^{\mathrm{a}}$ & $22,17 \pm 10,51^{\mathrm{a}}$ \\
Jumlah calon bunga (kuncup) & $5,11 \pm 3,01^{\mathrm{a}}$ & $5,30 \pm 2,85^{\mathrm{a}}$ & $0,80 \pm 0,80^{\mathrm{b}}$ & $5,07 \pm 3,14^{\mathrm{a}}$ & $5,20 \pm 3,07^{\mathrm{a}}$ \\
Jumlah bunga mekr* (kuntum) & 5
\end{tabular}

$\mathrm{LT}=$ lahan terbuka, RK=rumah kaca, NB=naungan Bauhinia, NG=naungan Glyricidia sepium , dan NI=naungan Indigofera; Superskrip yang berbeda pada baris yang sama menunjukkan perbedaan nyata pada $p<0,01$; *Superskrip yang berbeda pada baris yang sama menunjukkan perbedaan cenderung nyata pada $p<0,1$

\section{DAFTAR PUSTAKA}

Adigun J, Osipitan A, Lagoke S, Adeyemi R, \& Afolami S. 2014. Growth and yield performance of Cowpea (Vigna Unguiculata (L.) Walp) as influenced by row-spacing and period of weed interference in South-West Nigeria. Journal of Agricultural Science Archives. 6 (4) :188-198

AOAC. 2005. Official Method of Analysis of the Association of Official Analitycal Chemists. $16^{\text {th }}$ ed. Maryland (US): AOAC International. William Harwitz (ed)

Grubben JH. 2004. Vegetables. PROTA (Plant Resources of Tropical Africa) Foundation. Wageningen (NL): PROTA

Khalil. 2016. Crude nutrient and mineral composition of Asystasia gangetica (L.) as predominant forage species for feeding of goats. Pakistan Journal of Nutrition 15 (9): 867-872

Kumalasari NR \& Sunardi. 2014. Keragaman vegetasi potensial hijauan pakan di areal persawahan pada kondisi ketinggian yang berbeda. PASTURA: Jurnal Ilmu Tumbuhan Pakan Ternak. 4 (2): 59-61

Kumalasari NR, Permana AT, Silvia R, \& Martina A. 2017a. Interaction of fertilizer, light intensity and media on maize growth in semihydroponic system for feed production. 2017. Prosiding Internasional ISTAP 7. Yogyakarta (ID) : Universitas Gajah Mada.

Kumalasari NR, Rosadi K, \& Abdullah L. 2017b. Evaluasi pengaruh faktor iklim pada pembentukan rangkum bunga dan Polong Indigofera zollingeriana. PASTURA : Journal of Tropical Forage Science. $7(2): 103-105$

Kumalasari NR, Wahyuni L, \& Abdullah L. 2018a. Germination of Asystasia gangetica seeds exposed to different source, color, size, storage duration and pre-germinative treatments. Proceeding of The $4^{\text {th }}$ Intenational Seminar on Animal Industry. Bogor (ID). : Fakultas Peternakan IPB

Kumalasari NR, Abdullah L, Khotijah L, Indriani, Janato F \& Ilman N. 2018b. Pertumbuhan dan produksi stek batang Asystasia gangetica pada umur yang berbeda. Prosiding Seminar HITPI VII. Barjarmasin (ID) : Himpunan Ilmuwan Tanaman Pakan Indonesia.

Putra RI. 2018. Morfologi, produksi biomassa dan kualitas ara sungsang (Asystasia gangetica (L.) T. Anderson) sebagai hijauan pakan di beberapa wilayah Jawa Barat dan Banten. [skripsi] Fakultas Peternakan. Institut Pertanian Bogor. Bogor (ID).

Ramdani D, Abdullah L \& Kumalasari NR. 2016. Analisis potensi hijauan lokal pada sistem integrasi sawit dengan ternak ruminansia di Kecamatan Mandau Kabupaten Bengkalis Provinsi Riau. Buletin Makanan Ternak104 (1): 1-8

Rastogi A, Siddiqui A, Mishra Bk, Srivastava M, Pandey R, Misra P, Singh M \& Shukla S. 2013. Effect of auxin and gibberellic acid on growth and yield components of linseed (Linum usitatissimum L). Crop Breeding and Applied Biotechnology. 13: 136-143

Rijkers T, Pons TL \& Bongers F. 2000. The effect of tree height and light availability on photosynthetic leaf traits of four neotropical species differing in shade tolerance. Functional Ecology. 14: 7786

Shao Q, Wang H, Guo H, Zhou A, Huang Y, Sun Y \& Li M. 2014. Effects of shade treatments on photosynthetic characteristics, chloroplast ultrastructure, and physiology of Anoectochilus roxburghii. PLoS ONE. 9 (2): e85996.

https://doi.org/10.1371/journal.pone.0085996
Skalický V, Kubeš M, Napier R \& Novák O. 2018. Auxins and Cytokinins-The role of subcellular organization on homeostasis. International Journal of Molecular Science 19 (3115): 1-21

Tjitrosoedirdjo SS. 2005. Inventory of the invasive alien plant species in Indonesia. Biotropia. 25: 60-73 